\title{
Iraqi-Kurds from Political Stability to Political Upheaval: 2005 - 2017
}

\author{
Handren Ahmad Eahya \\ Ministry of Higher Education and Scientific Research, Soran University, Faculty of Law and International \\ Relations, International Relations Department KURDISTAN REGION IRAQ
}

\begin{abstract}
Following the change of Iraqi political system in 2005, Iraqi Kurdistan has been granted autonomous region within unified Iraq. Since then, Iraqi Kurds have sought to bring the old dream of independence into reality through political stability. Politically, it was the most stable period. However, these period of prosperity and stability have been dramatically changed into upheaval and crisis. KRG's politically they are in disputes. The unilateral Kurdish referendum in September, 2017 has brought almost the Kurdish dream of independence into unthinkable by losing most the political privileges they have. While the referendum has encouraged Iraqi government to take action against the KRG, it cannot be alone accounted for the political the KRG is in now. The KRG was in deep crisis even before the referendum. Thus, the main purpose of this research is to answer the question, "What accounts for the KRG's political upheaval?" How can we understand the political change? The study aims at achieving the following goals: First, understanding what has gone done in relations to state building in the Iraqi Kurdistan. Second, assessing the political system in IK by dealing with the administrative system, especially political parties to understand their relationship and the impact of this relation on the political system in IK. The objectives of the study are: The research attempts to clarify the political structure of IK. And what accounts for the dramatic change? The rationale of the research can be justified by numerous reasons. First, it is the desire of the Kurdish people to establish an independent democratic political system in the region where authoritarianism and dictatorship is a model of the political system. Secondly, the study is significant because of the on-going Kurdish issue in Iraq, Turkey, Iran and Syria. Methodology, the study will draw on the existing literature about the political system in countries to explain the political stability in IK. Therefore, the research will use the conceptual approach. The methodological approach used in this research is a qualitative argument, drawing on indication from policy literature and scholarly, non-governmental reports and governmental databases in order to gain a wide-ranging and accurate understanding of the research question which is what accounts for the political upheaval?
\end{abstract}

Keywords: Iraq, Kurdistan, Political upheaval.

DOI: $10.7176 / \mathrm{JLPG} / 96-05$

Publication date: April $30^{\text {th }} 2020$

\section{A brief view about Iraqi Kurdistan}

In 1991, Iraqi Kurds upraised against Saddam Husain's regime in North of Iraq with the help of western courtiers like the USA, Britain, and France. At the result of this they established safe heaven (no fly zone) for Iraqi Kurds. This is because Iraqi Kurds faced violence and discrimination under previous Iraqi governments, especially Baath's Regime. That's why the Kurdish people no longer wanted to live under the rule of Saddam Hussein (Gunter, 1993, p.295). After that Iraqi Kurds could not cooperated together, especially two main political parties were failed to join together in the new region. At the result for this there was civil war between them from 1994 until 1998. And Kurdistan region divided between two administrative Erbil (Yellow Zone) and Suleimanya (Green Zone), which was led by two main political parties Kurdistan Democratic Party (KDP) and Patriotic Union Kurdistan (PUK) (Stansfield, 2003, p.1). After 2003, when the USA decided according to their strategy, War on Terror, to attack Iraq and Saddam Husain's regime in order to change the political system from dictatorship to democracy (Gardner, 2005). This time was a most stable political period for Iraqi Kurds, this is because two main political parties KDP and PUK together run a coalition government, which was supervised by the USA. These mean that 'No - fly -zone' established for Kurds, and 2003 Iraq war led by America could be viewed the most critical events that allowed the Kurds in Iraq to redefine themselves and their identity. These events allowed the Kurds to revive their identity regionally and globally. And the KRG is a recognized as a political entity (Kockayne and Malone, 2006).

\section{The political system in KRG}

Heslop (2014) defines the Political system, as "the set of formal legal institutions that constitute a "government" or a "state."” (Heslop, 2014:1). Since 1991 Iraqi Kurdistan administrate three governorates (Erbil, Suleimanyah, and Duhok) in north of Iraq and tried to establish governmental institutions. For example, in May 1992, Iraqi Kurds for first time founded and elected their free Parliament (Gunter, 1993: 295). However, since that time until 2005 nobody officially recognized KRG as a political entity. In addition, after changing the political system in Iraq from dictatorship to democracy which was led by the USA, KRG officially recognized as a political entity 
internally, regionally, and internationally. And now according to the Iraqi Constitution in 2005, Iraqi Kurdistan is an autonomous region (article 4) (Iraqi Constitution, 2005).

Moreover, the main principles of any political system are the recognition of the government, which allows authority to use its power. As Dahl in his great definition stated that there is a great relationship between power, rule, and authority. This shows that legal authority can use its power to force anyone to obey its orders (Ramaswamy, 2015:52). In addition, the authority has legitimacy and rightful power to threat its people (Political Science, 2017). Here, the KRG provide facilities to Iraqi Kurds at the same time KRG can use its power to insist taxes and threat on their citizen who violate order.

Furthermore, the political system defines the relations between administrative system with its powers like parliament, judicial, and government in KRG. In most countries, this relationship between these powers have organized through their constitution. However, in KRG there has not a completed constitution yet. Even though there is a draft constitution, which was proved by parliament since 2009, but it has not in to vote by Iraqi Kurds. Lack of constitution make the situation more worth. This is because there is not balance of power between these three branches of administrative system. Due to this separation of authority to protect select in check and authorize persons (Fatah, 2016: 89-91).

There is a controversial debate within opposition group and authority over whether to have parliamentary or presidency system in Iraqi Kurdistan (Phillips, 2015:10-12). Opposition groups argue that the political system must be parliamentary model. They believe that the parliamentary model is more suitable to the region. This is because the parliamentary system make a difficulty for those who control the power for long time (Ala-Aldeen, 2016). In other words, the presidential system produce another dictatorship system. likewise, authority group like PDK and PUK, argue that the political system must be presidential model. This is because the situation in the Middle East, especially in Kurdistan Region needs this model of system. In other words, there are different political ideology in the region. This needs the central power in order to control them (FCSO, 2016:3-8). This means that there are two different models which is presented by both sides about the political system in the region. Hence, settle the debate peaceably over whether to have a parliamentary system, a presidential system or a hybrid of the two (Phillips, 2015:10-12).

This indicates that there was a negative view about this political entity in the region. This is because elite groups in KRG are more interested in self style business rather than establishing a strong government that brings about prosperity to their citizens. For example, the two armed political parties are reluctant to unify Peshmarga Forces. They are still two arm forces such as 70 brigade forces and 80 brigade force. There are other important scoters in the region such as police and secret agents that has not been unified. In other words, partisan loyalties by both PDK and PUK still rule supreme (Fumerton and Wilgenburg, 2016).

The positions of PDK and PUK have negative affect in the political system in the region. Two main political parties PDK and PUK rule for almost three decades in the region. They affect every single aspect in the region. Both of them controlled whole important sectors in the region. Especially, power and economy are under their control. Politically, they have divided main political positions between themselves. For example, the position of the president of Iraq and the parliament speaker in Kurdistan Region Government (KRG) are for PUK and the positions of President of KRG and Prime minister for PDK (Jabary and Hira, 2013). Economically, main political parties increasing wealth through corruption need to create an environment where they can easily hide corrupt activities and protect their wealth at the same time. To achieve this end, they struggle to monopolize the institutions of governance by employing those close to them who obey their orders. These kinds of governance lead to weaknesses in the system of checks and balances (Fatah, 2016: 194-195).

Moreover, another problem that political parties in Iraqi Kurdistan have is a personalization of power. This is because the political stability depends on one person. It means that when the person is gone, a political upheaval is emergence. For instance, when the head of PUK (Jalal Talabani) died and the head of change movement, Nawshirwan Mustafa, passed away, the political vacuum and instability ensue (Al Jazeera, 2018).

In addition, what I have mentioned above, the conflict with Islamic State in Iraq and Syria (ISIS) is reshaping regional dynamics in a way that will likely affect the course of Kurdish politics for short period. Especially, the emergence of a common Kurdish public sphere in terms of cooperation between main political parties like PKK, PDK and PUK. For instance, the PKK provided support to the Kurdistan Regional Government (KRG) in defense of Makhmour, Mount Sinjar, Kirkuk, and other places which became ultimate threat to the survival of KRG. The KRG sent Peshmarga to Kobani to assist YPG forces. Also, the KRG's parliament recognized the three PYD administered cantons in northern Syria, or Rojava in Kurdish (A1 Jazeera, 2015: 2-5).

These developments have created a foundation for the significant level of delight and confidence amongst the Kurds. Declarations of Kurdish unity and the international status of Kurdish politics have dominated the titles of publications related to the Kurdish national movement. Even beyond the political class, some scholars of Kurdish affairs have claimed that the Kurds have never before attained such a level of influence in regional politics and international legitimacy. Such analysis encouraged and confirmed Kurds in their self-confidence and selfcongratulation. 
Though it is valid to say that the fight against ISIS has bestowed further legitimacy upon the aspiration of Kurdish national movements, one still should be wary of bold pronouncements that "the Kurdish time has arrived" (Jungbluth, 2015: 9-10).

Though the security and economic costs of the war against ISIS in the region have affected the Kurdistan Regional Government in terms of economy, human casualties, and rise of refuges in the region. However, the war against ISIS could have been an opportunity if the Kurds had a political and economic capacity to accomplish victory over ISIS. And one of the most important point is the control of Kirkuk by Peshmerga Forces, which could greatly rise the chance of establish their own state in the long term as well as growing the ability of KRG to export their natural sources, especially oil and gas (Stansfield, 2014).

The referendum also exacerbated tensions within Iraqi Kurdistan's already divided political landscape. Group of oppositions such as the Change Movement and other Islamic Parties, both stated a refuse of the referendum, only to opposite their places hours before the vote began. This showed the parties' unpredictable support of the referendum process and a hope to restart parliamentary act post-referendum.

The internal political divide within PUK and between PUK and PDK had ended Kurdish independent for now. Handing over the rich oil city of Kirkuk to the Iraqi Army by PUK Peshmarga forces is the example of that. On 16 October 2017, some politicians within PUK party had secret deal with then Prime Minister Abadi to abandon Kirkuk city and hand over to the Iraqi Army. The PUK's unpredicted agreement to Baghdad is seen by some Kurdish leaders as a betrayal. This is due to the fact that the KRG was relying on Kirkuk natural resources to pay back its own debts; KRG is in debt billions US dollars. To sum up, Barzani's bid of independence was unsuccessful. This is mainly due to the political divide within PUK and between PUK-PDK. The disagreement along elite groups in the region and to predict that the incomplete support of the PUK for the referendum would conclude in the loss of Kirkuk (Klain and Hintz, 2017).

\section{Challenges Barzani had experienced}

First, exacerbated internal cleavages threaten the KRG's reputation as a democratizing government. This is because Barzani stayed in power as a president for two more years, after his presidency ended. His extension of terms without the will of the people and/or parliamentary support as an illegitimate president (ORSAM, 2017). Second, although it has become the West's favorite fighting force, the Peshmerga still faced challenges. Most notably, it is not unified. The KDP and PUK each control their own separate militias, which administer different territories (Fumerton and Wilgenburg 2016). Third, the center-periphery relationship between Baghdad and Erbil is not clear, and is still hotly disputed. The issues of oil and gas and the "contested" territories continue to loom (Al-Nidawi, 2019). Fourth, the Kurdistan Region suffers from an economic crisis that further threatens the moment. Erbil remains dependent on revenues from Baghdad for over 90 percent of its state budget. During times of tension and dispute, the central government cuts its revenue stream and hampers the KRG. The Kurdish leadership began courting international oil companies (IOCs) during the country's post-conflict oil rush, which started in 2007, in order to limit dependence on the central government. However, the recent drop in the price of oil has greatly affected the sub-state's economy and ended the initial rush. More critically, it exposed the rentier nature of the KRG's dependence on oil. The government is not able to pay the International Oil Companies (IOC) as it has promised, and the economy has tanked. The KRG also faces difficulties paying state salaries. The promise of a "new Dubai" has become a distant memory, and the inability to export sufficient amounts of oil independently and thereby reach economic sustainability delays the Kurdish moment (MERI, 2016: 32-38). Out of these four challenges, the latter two present the biggest impediments. If Erbil continues its conflict with Baghdad, and if it is unable to recover from its current economic crisis, the KRG will not be able to take full advantage of the current moment of opportunity and will remain stagnant.

In conclusion, this paper set out to investigate a suitable answer to "What accounts for the KRG's political upheaval?" and it also explore reasons that have resulted to dramatic change in political system in the region. Thus, the paper also required to framework the main challenges in the political system in KRG. Especially, the political instability in Iraqi Kurdistan has become more apparent since the withdrawal of Peshmerga Forces in the oil rich city of Kirkuk and decontrolled by federal forces in 16 October 2017. And later with the resigned of President Masood Barzani in his office as the result of ending his presidential period. Now (and Massoud Barzani's son) Masrur Barzani was appointed to form the new cabinet. At this point, the following significant questions seek answers in this new period: How is the opposition party going to react? Whether the process of forming a new cabinet is going to create a political crisis? And how Erbil, which has a sufficiently of matters with Baghdad will act during this new period.

\section{References}

Al Jazeera (2015) Regional Kurdish politics in the Post-ISIS period [Online]. Available from: $<\mathrm{http} / /$ studies.aljazeera.net/mritems/Documents/2015/2/11/201521184816628734Regional\%20Kurdish\%2 OPolitics.pdf $>$. [Accessed 3 May 2019]. 
Al Jazeera (2018) Is Iraqi Kurdistan on the verge of another civil war? [Online]. Available from : https://www.aljazeera.com/indepth/opinion/iraqi-kurdistan-verge-civil-war-180928115350018.html> [Accessed 3 May 2019].

FCSO (2016) Resolution to the political crisis in the Iraqi Kurdistan Region [Online]. Available from: < http://www.kie-ngo.org/newdesign/Hawpichekan/pltclres.pdf >. [Accessed 25 April 2019].

Fumerton, M. and Wilgenburg, W. (2016) Kurdistan's political armies: the challenges of unifying Peshmerga Forces [Online]. Available from: <https://carnegiemec.org/2015/12/16/kurdistan-s-political-armieschallenge-of-unifying-peshmerga-forces-pub-61917>. [Accessed 3 May 2019].

Gardner, H. (2005) American global strategy and the 'war on terrorism'. ${ }^{\text {st }}$ edn. England: Ashgate.

Gunter, M. M. (1993) A de facto Kurdish state in Northern Iraq, Third World Quarterly [Online]. 14(2), pp. $295-$ 319. <https://www.aljazeera.com/indepth/opinion/iraqi-kurdistan-verge-civil-war-180928115350018.html>.

Iraqi Constitution (2005) [Online]. Available from: $<$ http://www.iraqinationality.gov.iq/attach/iraqi_constitution.pdf $>$. [Accessed 23 April 2015].

Jabary, K. and Hira, A. (2013) The Kurdish Mirage: A success story in doubt. Middle East Policy Council. 20(2) Summer, pp. 99-112.

Jungbluth, S. (2015) The future of Iraqi Kurdistan: the 'Islamic State' as a catalyst for independence? [Online]. Available from: <http://www.peace.ax/images/Silke_Jungbluth_Working_Paper_Kurdistan_FINAL.pdf $>$. [Accessed 3 May 2019].

Kockayne, J. and Malone, D. (2006) Creeping Unilateralism: how operation provide comfort and the No-Fly Zones in 1991 and 1992 paved the way for the Iraq crisis of 2003 [Online]. Available from: $<$ https://journals.sagepub.com/doi/abs/10.1177/0967010606064138> [Accessed 3 May 2019].

Phillips, D. (2015) State-Building in Iraqi Kurdistan. $1^{\text {st }}$ edn. Colombia University: New York.

Political Science (2017) Political system: meaning and characteristics of a political system [Online]. Available from: $\quad<\mathrm{http} / /$ www.politicalsciencenotes.com/articles/political-system-meaning-and-characteristics-of-apolitical-system/356>. [Accessed 19 April 2019].

Ramaswamy, S. (2015) Political Theory: ideas and concepts. $2^{\text {nd }}$ edn. PHI Learning Private Limited: Delhi.

Fatah, S. (2016) A study of implementation of the constitution and the quality of governance in Kurdistan. [Online]. Available from: $<$ http://researchonline.ljmu.ac.uk/id/eprint/4820/1/2016\%20\%20FatahPhD.pdf $>$. [Accessed 10 May 2019].

Stansfield, G. (2014) the Islamic State, the Kurdistan Region and the future of Iraq: assessing UK Policy Options. Insertional Affairs [Online]. 90 (6) November, pp. 1329-1350. Available from: $<$ https://academic.oup.com/ia/article-abstract/90/6/1329/2326776> [Accessed 10 May 2019].

Ala-Aldeen, D. (2016) State-building in a fragmented Kurdistan Region of Iraq. MERI Policy Brief [Online]. 3(13) August, pp. 1-3. Available from: <MERI-Policy-Brief-2016-vol-3-No-13-AlaAldeen-Fragmentation-StateBuilding.pdf $>$. [Accessed 10 May 2019].

MERI (2016) In best of times and worst of times: addressing structural weaknesses of the Kurdistan Region's economy. [Online]. Available from: <http://www.meri-k.org/wp-content/uploads/2016/01/MERI-EconomicReport-January-2016-2.pdf $>$. [Accessed 11 May 2019].

ORSAM (2017) Is the End of Masud Barzani's Period? [Online]. Available from $<$ https://orsam.org.tr/en/is-theend-of-masoud-barzani-period/>. [Accessed 11 May 2019].

Al-Nidawi, O. (2019) Finding away forward in the Baghdad-Erbil dispute [Online]. Available from $<$ https://www.mei.edu/publications/finding-way-forward-baghdad-erbil-oil-dispute>. [Accessed 11 May 2019].

Klain, K. and Hintz, L. (2017) A series of miscalculations: the Kurdish referendum and its fallout [Online]. Available from: $<$ https://reliefweb.int/report/iraq/series-miscalculations-kurdish-referendum-and-itsfallout $>$. [Accessed 11 May 2019]. 